MATEC Web of Conferences 48,01007 (2016)

DOI: $10.1051 /$ matecconf $/ 20164801007$

(C) Owned by the authors, published by EDP Sciences, 2016

\title{
Power processing unit for hall-effect thrusters on "Meteor-M №3 spacecraft"
}

\author{
Anton Moshnyakov ${ }^{1,2,}$, Maxim Mikhaylov ${ }^{1,2}$ \\ ${ }^{1}$ National Research Tomsk Polytechnic University, 634050 Tomsk, Russia
}

\begin{abstract}
The development results of power processing unit (PPU-M) for hall-effect thrusters on «Meteor-M №3» spacecraft are considered. The structure, weight, dimensions and main technical characteristics of the system in the paper are presented. The work peculiarity of the system is unstable input voltage of both power bus and control bus that increases the ripple voltages and currents at the input and the output and causes the additional requirements to the circuit design. A comparative analysis of the system characteristics and European analogs was carried out, and then a conclusion on the basis of available data that the characteristics of the system are not inferior to European analogs was made.
\end{abstract}

\section{Introduction}

Power processing unit provides the required modes of two SPT-100 (Stationary Plasma Thruster) thrusters installed on board of «Meteor-M №3» spacecraft and designed to station-keeping during the whole lifetime (7 years) and then to inject into Graveyard orbit. PPU-M is suitable for operation in open space and provides the required power supply modes for the loads shown in Table 1.

Table 1. Loads of PPU-M.

\begin{tabular}{|c|c|c|c|c|c|}
\hline Load type & SPT-100 & $\begin{array}{c}\text { Thruster } \\
\text { valves }\end{array}$ & $\begin{array}{c}\text { Xenon storage } \\
\text { bank valves }\end{array}$ & Pyrovalves & $\begin{array}{c}\text { Xenon flow } \\
\text { regulators }\end{array}$ \\
\hline Quantity, pes & 2 & 12 & 6 & 2 & 2 \\
\hline
\end{tabular}

\section{PPU-M Design}

PPU-M is designed as a monoblock and has two channels of power supply, each of which supplies the power for one thruster (Figure 1).

Structurally, PPU-M consists of 14 modules installed on a common base, connected by a bus and closed by a protective cover. Figure 2 shows a power supply circuit of one SPT-100 thruster type.

${ }^{\text {a }}$ Corresponding author : polus@online.tomsk.net

${ }^{2}$ JSC «Scientific and industrial Centre «Polyus», 634050 Tomsk, Russia 


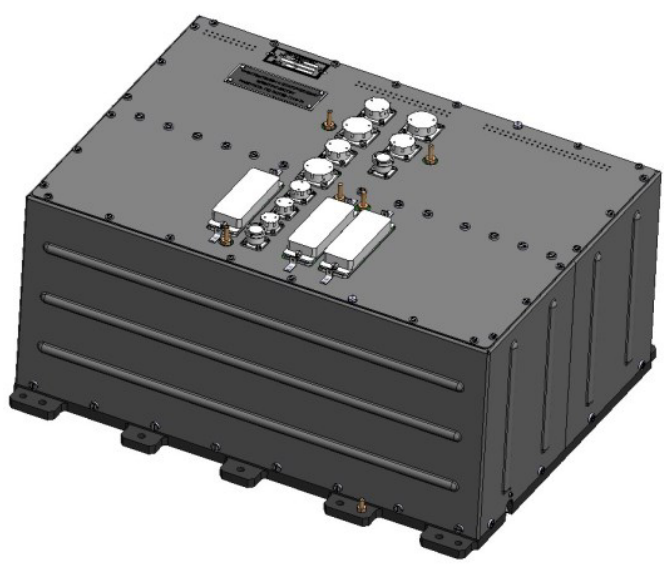

Figure 1. PPU-M mechanical design.

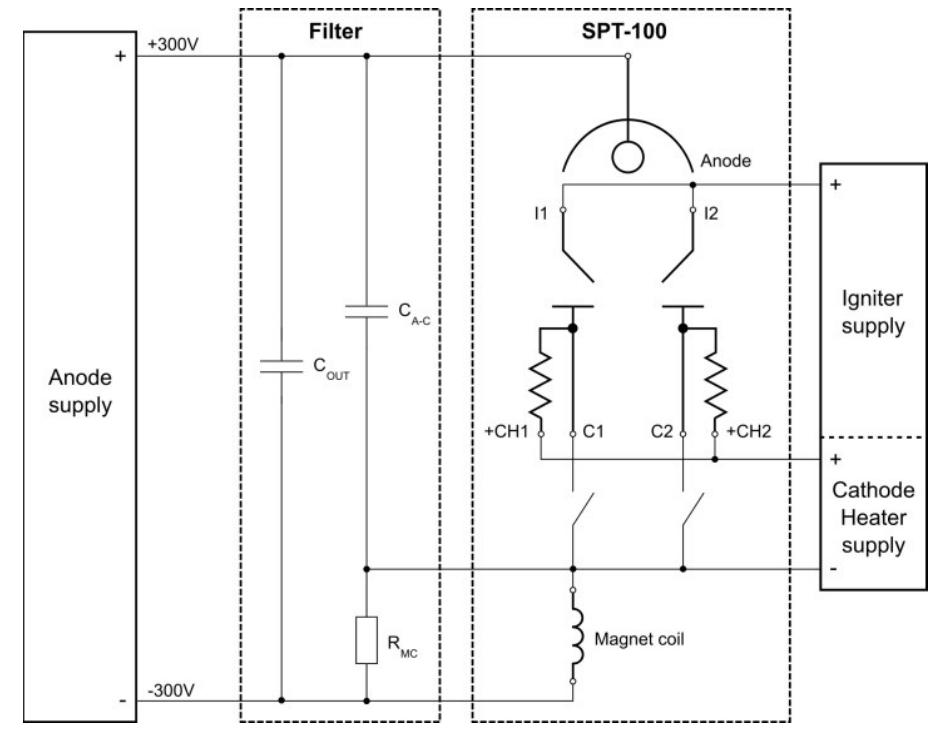

Figure 2. Power supply circuit of SPT-100: $\mathrm{CH}$ - Cathode Heater; $\mathrm{C}$ - Cathode; I - Ignition Electrode; $\mathrm{C}_{\mathrm{A}-\mathrm{C}}-$ anode-cathode capacitor; $\mathrm{C}_{\mathrm{OUT}}-$ output capacitor; $\mathrm{R}_{\mathrm{MC}}$ - magnetic coils ballast resistor.

\section{PPU-M Specifications}

PPU-M work peculiarity is unstable input voltage: in the power bus it varies in the range of $46-65 \mathrm{~V}$, and the control bus in the range of $24-34 \mathrm{~V}$. Pulsed power consumption from input sources and as a result increasing of their ripple currents and voltages are caused by this fact. A throttle is installed and value of anode supply input filter capacitor is increased to reduce them. The value of $\mathrm{C}_{\mathrm{OUT}}$ capacitor is increased to reduce the voltage ripple in the anode circuit. The value of $\mathrm{C}_{\mathrm{A}-\mathrm{K}}$ capacitor will be determined in the process of thruster connecting tests.

The power supply circuit of magnetic coils for SPT-100 is worked out using discharge current that eliminates additional source and reduces the weight of the device. For the same purpose the original cathodes circuit switching scheme is used, that allows switching cathode heater, cathode and the ignition electrode circuit using only one key.

In addition to the power supply sources, PPU-M has a built-in filter for protection against anode, cathode and ignition electrode circuit static electricity. 
Main technical characteristics of PPU-M are given in Table 2.

Currently laboratory PPU-M sample is manufactured and developmental testing is being completed.

Table 2. Main characteristics of PPU-M.

\begin{tabular}{|c|c|c|}
\hline Parameter & Value & Note \\
\hline Discharge voltage, $\mathrm{V}$ & $300 \pm 15$ & DC \\
\hline Discharge current, A & $4,5 \pm 0,1$ & In a start mode up to $7 \mathrm{~A}$ for $2-4 \mathrm{sec}$ \\
\hline Cathode heater current, $\mathrm{A}$ & $12,0 \pm 0,5$ & $0,2 \mathrm{Ohm}<R_{C H}<0,7 \mathrm{Ohm}$ \\
\hline \multirow{2}{*}{ Xenon flow regulators current, $\mathrm{A}$} & $1,5-1,75$ & Preparation mode \\
\hline & $0 ; 3,8 \pm 0,2$ & Operating mode \\
\hline \multirow{2}{*}{ Ignition pulses voltage, $\mathrm{V}$} & $290-350$ & $\begin{array}{c}R_{I E}=10 \pm 1 \mathrm{kOhm} ; f=145 \pm 15 \mathrm{~Hz} \\
t_{I}=70-140 \mathrm{mks}\end{array}$ \\
\hline & $20-40$ & $\begin{array}{c}R_{I E}=5,0 \pm 0,5 \mathrm{Ohm} ; f=145 \pm 15 \mathrm{~Hz} \\
t_{I}=70-140 \mathrm{mks}\end{array}$ \\
\hline \multirow{2}{*}{ Thruster valves voltage, $\mathrm{V}$} & $22,3-32,7$ & Switch-on mode \\
\hline & $8-13$ & Hold mode \\
\hline \multirow{2}{*}{$\begin{array}{l}\text { Xenon storage bank valves } \\
\text { voltage, } \mathrm{V}\end{array}$} & $22,3-32,7$ & Switch-on mode \\
\hline & $8-13$ & Hold mode \\
\hline \multirow{2}{*}{ Pyrovalves current, A } & $3-5$ & $0,8 \mathrm{Ohm}<R_{P V}<1,2 \mathrm{Ohm}$ \\
\hline & $0,005-0,015$ & Flow mode \\
\hline Power bus voltage, $\mathrm{V}$ & $46,9-65,3$ & $\begin{array}{l}\text { Power consumption in operating mode less than } \\
1500 \mathrm{~W}\end{array}$ \\
\hline Control bus voltage, $\mathrm{V}$ & $24-34$ & Power consumption less than $80 \mathrm{~W}$ \\
\hline Command quantity, pcs & 17 & Single commands \\
\hline \multirow{2}{*}{$\begin{array}{l}\text { The number of telemetry channels, } \\
\text { pcs }\end{array}$} & 8 & Analog, $0 \mathrm{~V}<U_{T M}<5 \mathrm{~V}$ \\
\hline & 8 & Signal \\
\hline Reliability & 0,999 & $\begin{array}{l}\text { Active lifetime is } 7 \text { years long; operating time is } \\
1000 \text { hours long }\end{array}$ \\
\hline Weight, kg & 17 & \\
\hline
\end{tabular}

\section{Comparative analyses}

Existing analogues characteristics analysis was performed in the development phase. Main results are shown in Table 3.

The nearby analogue of the PPU-M is PPU Mk1 for Stentor spacecraft [1] because both of them operate with two thrusters type SPT-100. A significant difference in the weight of these PPUs is due to the principally different structure of design. PPU Mk1 for Stentor spacecraft contains one power supply channel and one switch module for two thrusters [2], a single failure of any element results in failure of the whole system. Only «cold» redundancy using two PPU on board is operated in this spacecraft.

In addition, unlike the PPU for Stentor and Smart-1 spacecraft, powered by a stabilized [3] power bus $50 \mathrm{~V}$, in PPU-M the power supply is unstabilized (24 -34 and $46-65)$ that includes a built-in PPU stabilizer. Also the PPU-M includes a built-in filter for protect against electrostatic discharges, which is submitted as a separate and independent unit of the propulsion system in European PPU. 
Table 3. Main specifications of several domestic and foreign PPU-M for thrusters SPT-100.

\begin{tabular}{|c|c|c|c|c|c|c|c|c|}
\hline \multirow{2}{*}{$\begin{array}{l}\text { Name of } \\
\text { system }\end{array}$} & \multirow{2}{*}{$\begin{array}{c}\text { Start of } \\
\text { operation }\end{array}$} & \multicolumn{2}{|c|}{ Thruster } & \multirow{2}{*}{$\begin{array}{c}\text { Weight } \\
\text { of PPU, } \\
\text { kg }\end{array}$} & \multirow{2}{*}{$\begin{array}{l}\text { Power } \\
\text { supply } \\
\text { bus, W }\end{array}$} & \multicolumn{2}{|c|}{ Anode supply } & \multirow{2}{*}{$\begin{array}{c}\text { Cathode } \\
\text { heater } \\
\text { current } \mathbf{I}_{\mathrm{CH}} \text {, } \\
\text { A }\end{array}$} \\
\hline & & Type & Quantity & & & $U_{A}, \mathbf{V}$ & $\begin{array}{l}P_{A}, \\
\mathrm{~kW}\end{array}$ & \\
\hline $\begin{array}{c}\text { PPU - 2EA } \\
\text { (SIC "Polyus") }\end{array}$ & 2013 & SPT-100 & 8 & 27,1 & 27,100 & 300 & 1,4 & 12 (DC) \\
\hline $\begin{array}{l}\text { PPU-M (SIC } \\
\text { "Polyus") }\end{array}$ & 2015 & SPT-100 & 2 & 17 & $\begin{array}{c}24-34 \\
46,9- \\
65,3\end{array}$ & 300 & 1,4 & 12 (DC) \\
\hline $\begin{array}{l}\text { PPU Mk1 for } \\
\text { Stentor } \\
\text { spacecraft }\end{array}$ & 2002 & $\begin{array}{l}\text { SPT-100 or } \\
\text { PPS-1350 }\end{array}$ & 2 & 10,4 & 100 or 50 & $\begin{array}{c}300 \text { or } \\
350\end{array}$ & 1,6 & 14 (DC) \\
\hline $\begin{array}{l}\text { PPU Mk1 for } \\
\text { Smart-1 } \\
\text { spacecraft }\end{array}$ & 2003 & PPS1350-G & 1 & 10,9 & 50 & $\begin{array}{c}175- \\
350\end{array}$ & $\begin{array}{c}0,306 \\
-1,225\end{array}$ & No data \\
\hline
\end{tabular}

Based on the above it can be concluded that the build structures of PPU-M and PPU (Stentor) are significantly different, that greatly complicates the identification of their specific characteristics. To ensure a high level of reliability for PPU it is required to install a redundant unit. The vast majority of foreign PPU-M analogues have a remote filter unit, whose weight is not considered.

\section{Conclusion}

Designed PPU-M ensures reliable operation of two SPT-100 type thrusters as part of «Meteor-M №3» spacecraft in open space with unstable input voltage. For functional and specific weight and size characteristics PPU-M is superior to foreign analogs due to the original circuit switching cathodes and monoblock design.

\section{References}

1. E. Bourguignon, T. Scalais, J. Thomas, ESA SP 555, 447 (2004)

2. P. Garnero, T. Grassin, F. Darnon, L. Petitjean, IEPC, 048 (2003)

3. E. Bourguignon, S. Fraselle, T. Scalais, IEPC, 095 (2011) 